\title{
EFFECT OF NIGELLA SATIVA ON GROWTH PERFORMANCE AND SOME BLOOD CONSTITUENTS OF NILE TILAPIA (OREOCHROMIS NILOTICUS)
}

\author{
S.Y. HUSSEIN ${ }^{1}$, K.F.M. ABOUELEZZ ${ }^{2}$, M.I. EL-KELLAWY ${ }^{3}$ AND DOA, Y.A. ${ }^{4}$ \\ ${ }^{1}$ Prof. of Fish Physiology - Dept. of Poultry Production -Fac. of Agri. Assiut University \\ ${ }^{2}$ Associate Prof. Dept. of Poultry Physiology -Fac. of Agri. Assiut University \\ ${ }^{3}$ Associate Prof. Dept. of Poultry Nutrition -Fac. of Agri. New Vally \\ ${ }^{4}$ B.Sc. Poultry Production Dept. - Fac. of Agri. Assiut University
}

Received: 31 August 2020; Accepted: 1 October 2020

\begin{abstract}
A total number of 135 Nile tilapia (O. niloticus) were used to study the effect of dietary supplementation with black cumin seed (Nigella sativa) on growth performance and some blood constituents. The fish were randomly divided into three treatment groups each of 45 fish, and each group was divided into 3 subgroups (15 fish / unit). These groups received N. sativa at $1 \%$ (T1) and 2\% (T2) and control group (C) which fed on basal diet without $N$. sativa. Body weight and length were recorded biweekly all over the experimental period (12 weeks). Blood samples from each fish were collected to determine each of hemoglobin $(\mathrm{Hb})$, packed cell volume (PCV\%), serum glucose, total protein, albumin, globulin, and alkaline phosphatase. Ten fish were scarified to determine hepatosmatic index (HSI), spleen somatic index (SSI), and gonadosomatic index (GSI). Other ten fish were transported to wet laboratory and reared without oxygen supplementation to determine the resistance under oxygen deficiency. The results showed that there was insignificant increase in body weight, body weight gain, total length, and length increment in T2. Also, the hemoglobin increased insignificantly $(\mathrm{P}>0.05)$ in $\mathrm{T} 2$ than the control. Moreover, the serum albumin improved insignificantly $(\mathrm{P}>0.05)$ in $\mathrm{T} 1$ and $\mathrm{T} 2$ than the control. Serum alkaline phosphatase was significantly $(\mathrm{P}<0.05)$ increased in treated fish with $N$. sativa; while serum glucose decreased significantly $(\mathrm{P}<0.05)$ as compared with control ones. The hepatosoatic index (HSI) insignificantly $(P>0.05)$ decreased in T1 and increased insignificantly $(P>0.05)$ in T2 compared to the control. Also, the dietary 1 and $2 \% N$. sativa did not affect spleenosomatic index (SSI). The fish group which reared under oxygen deficiency exhibited remarkable decreased activity and increased random movement elicited by hypoxia changes in direction of swimming, while the fish groups fed diets with $N$. sativa showed slightly abnormal behavior changes. The mortality rates under oxygen deficiency were 100, 40 and $20 \%$ for control, T1 and T2, respectively. Under oxygen deficiency stress, the Hb and glucose did not differ between T1 and T2, while PCV\% was increased significantly $(P>0.05)$ in T2 than that of $\mathrm{T} 1$; the same occurred $(\mathrm{P}<0.05)$ with serum total protein concentration, globulin, and alkaline phosphatase activity, but serum albumin in T1 was higher than that of T2 (P < 0.05). There were no significant $(\mathrm{P}>0.05)$ in HIS, SSI and GSI between treated groups with $N$. sativa and control ones. To conclude, the dietary supplementation with $N$. sativa at $1 \%$ and $2 \%$ displayed slight beneficial effects on growth performance and major effects on some blood constituents of $O$. niloticus.
\end{abstract}

Keywords: Nigella sativa, growth, blood, Nile tilapia, feed supplements.

Corresponding author: Dr. S.Y. Hussein

E-mail address: Samir.youssif@agr.au.edu.eg

Present address: Prof. of Fish Physiology- Department of Poultry Production-Assiut University- Egypt. 


\section{INTRODUCTION}

In the world, very important investments have been made in cultural fisheries to meet the protein needs for humans. In parallel with the development of this industry, diseases and stress factors have also increased (FAO, 2016). For a healthy and efficient production, the main cause of these problems must be identified and solved. Tilapia is cultured in aquaculture farms all over the world. This fish has been recognized as the potential aquaculture fish species of the twenty-first century (Shelton, 2002). Among a number of species of tilapia (FAO, 2018), Nile tilapia (Oreochromis niloticus) is most widely cultured in a diverse group of aquatic environments because of its fast growth, stress tolerance, and reproduction both in freshwater and saline water condition (Chervinski, 1982; Abdel-Fattah and El-Sayed, 2006; Gibtan et al. 2008).

Currently, Egypt is one of the countries where aquaculture is growing fastest with Nile tilapia (Oreochromis niloticus) as the most widely farmed species. Unfortunately, intensive aqua-farming is accompanied with several problems where infectious diseases and oxygen deficiency come in limiting the production with consequent negative impact on growth, fecundity and productivity.

Due to the European Union has been decided prevent the use of antibiotic as feed additive in 2006, scientists have turned to research on natural medicines. According to many researchers, it has been reported that medicinal plant having many properties such as growth promotion, appetite stimulation, antimicrobial, immunestimulant, anti-inflammatory, anti-stress, and anticancer (Bulfon et al., 2013). Using natural feed additive is becoming useful for fish feeding rather than classic chemical feed additives due to the cumulative effects of the chemical components induced deterrent effects on human health (El-Dakar et al., 2008).

From these, $N$. sativa, which belongs to the Ranunculacea family, is a medicinal herb having many therapeutic characteristics (Ziaee et al., 2012). N. sativa has been used for treatment for more than 2000 years, which is commonly known as black cumin seed. N. sativa is native to Southern Europe, North Africa and Southwest Asia and it is cultivated in many countries in the world like Middle Eastern, Mediterranean region, South Europe, India, Pakistan, Turkey, and Saudi Arabia (Ahmad et al., 2013). N. sativa seeds and oils have been commonly used as treatment for a variety of health conditions pertaining to the respiratory system, digestive tract, kidney and liver functions, cardiovascular system, and immune system support, as well as for general well-being (Ahmad et al., 2013).

Moreover, black cumin (N. sativa) have been used as enhancer for performance, growth and immune system of some fish species (Abdel-Ghaffar et al., 2003; Diab et al., 2008) where the nutritional content is as follows: $20.8 \%$ raw protein, $3.7 \%$ raw cinder, $7.0 \%$ moisture, $34.8 \%$ fat and $33.7 \%$ carbohydrates (Atta, 2003). The main objective of this experiment, therefore, is to evaluate the effect of $N$. sativa on growth performance, some blood variables, in addition to immunity under oxygen deficiency in Nile tilapia $(O$. niloticus).

\section{MATERIALS AND METHODS}

One hundred and thirty five fish (Oreochromis niloticus) were collected from the experimental fish farm belonging to the Poultry Production Department, Faculty of Agriculture, Assiut University. All the experimental fish appeared to be clinically normal and in a good health at the experiment start. Average body weight and body length were $101 \pm 1 \mathrm{~g}$ and $18.11 \pm$ $0.41 \mathrm{~cm}$, respectively. The fish were reared 
in floating cage and adapted for two weeks in a water pond.

At the start of the experiment the fish were weighed and the total length was measured. Three experimental groups (45 fish each, 15/ subgroup) where distributed randomly as follow:

1 -The first group was considered as a control which fed on a basal diet (Table $1)$.

2 - The second group was fed on the basal diet supplemented with $1 \%$ Nigella Sativa.

3 - The third group was fed on the basal diet supplemented with $2 \%$ Nigella Sativa.

The dry ingredients of the experimental diets were thoroughly grinded, mixed and pelletized. The experimental fishes were offered the dietary treatments twice daily at
9.00 AM and 3.00 PM at a rate of $3 \%$ of their live body weight. The feed quantity was readjusted biweekly on the basis of the actual average biomass of the fish in each treatment.

\section{1- Growth variables}

The individual body weight $(\mathrm{g})$ and total body length $(\mathrm{cm})$ for all fishes per treatment were recorded biweekly. The average body weight gain (ABWG) was estimated according to the following equation:

Weight gain $=$ Average final weight $(\mathrm{g})-$ Average initial weight (g)

The body length increment $(\mathrm{cm})$ was estimated according to the following equation:

Length increment $(\mathbf{c m})=$ Average final length $(\mathrm{cm})$ - Average initial length $(\mathrm{cm})$

Table (1): Composition and Chemical analysis on dry matter basis) of the experimental basal diet

\begin{tabular}{lc}
\hline \multicolumn{1}{c}{ Ingredient } & Weight $(\mathrm{Kg})$ \\
\hline Yellow corn grain & 52 \\
\hline Soya bean meal & 22 \\
\hline Fish meal (72\% protein) & 25 \\
\hline Vitamin Mix. $^{1}$ & 0.5 \\
\hline Mineral Mix. $^{2}$ & 0.5 \\
\hline Total ingredients & 100 \\
\hline Calculated analysis & 30.44 \\
\hline Crude protein $(\%)$ & 4038.50 \\
\hline Gross energy (Kcal/Kg) &
\end{tabular}

${ }^{1}$ Vitamin Mix contained mg per kg diet: alpha tocopherol, 20; Menadione, 5; thiamine, 5; riboflavin, 5; calcium pantothenate, 10; piridoxine, 100; folic acid, 2; cyanocobalamin, 0.5; biotin, 0.5; ascorbic acid, 200; paminobenzoic acid, 50; inositol, 500; choline chloride, 500; (UI/kg diet): retinol 10000; cholecalciferol, 2000. ${ }^{2}$ Vitamin Mix contained mg per kg: cobalt sulphate, 0.4; copper sulphate, 5.0; iron sulphate, 40; sodium fluoride, 1.0; potassium iodide, 0.6; magnesium oxide, 100; manganesium oxide, 10; zinc oxide, 12.5 .

\section{2- Blood sampling}

At the end of the experimental period, 10 fish were randomly taken from each experimental group. Individual blood samples were collected by severing the caudal peduncle. Aqduate amounts of whole blood were collected in two small plastic vials; one containing heparin and one without anticoagulant. The first sample was used for determination of hemoglobin (Hb) by using suitable Kits and hematocrit (PCV) according to Stoskopf (1993).

The other sample was centrifuged at 3000 (rpm) for 15 minutes to obtain serum. The serum was stored at $-20 \mathrm{C}^{\mathrm{o}}$ until analysis. Serum total protein $(\mathrm{g} / \mathrm{dl})$, albumin $(\mathrm{g} / \mathrm{dl})$, alkaline phosphatase $(\mathrm{u} / \mathrm{l})$, and glucose 
$(\mathrm{mg} / \mathrm{ml})$ were determined calorimetrically using Kits purchased from the Egyptian company for biotechnology (S.A.E) Pharmaceutical Chemicals (Egypt). Globulin was calculated by difference between serum total protein and albumin. After blood sample collection, all the fish samples (10/group) were scarified and the abdominal cavity was opened to remove spleen, gonads and liver to be weighed. The gonad, liver and spleen indices were calculated as follow:

$\begin{array}{llll}\begin{array}{l}\text { Spleenosomatic } \\ \text { Spleen weight }(g)\end{array} & \text { index } & \text { (SSI) } \\ =\frac{\text { Body weight }(g)}{\text { Bod }} & \text { X100 } & & \\ \begin{array}{l}\text { Gonadosomatic } \\ \text { Gonad weight }(g)\end{array} & \text { index } & (\mathrm{GSI}) \quad= \\ \begin{array}{l}\text { Body weight }(g) \\ \text { Hepatosomatic }\end{array} & \text { index } & \text { (HSI) } & = \\ \begin{array}{l}\text { Liver weight }(g) \\ \text { Body weight }(g)\end{array} & X 100 & & \end{array}$

\section{3- Stress experiment (Oxygen deficiency):}

This experiment aimed to study the effect of Nigella Sativa on Nile tilapia (Oreochromis niloticus) under oxygen deficiency. Ten / treatment fish were transported to the aquaculture laboratory at the same farm; each group was distributed randomly into two sub-groups each was placed in a metallic aquarium $(1.5 \mathrm{~m} \mathrm{X} 0.6$ $\mathrm{m}$ X $0.5 \mathrm{~m}$ diameters and $180 \mathrm{~L}$ water capacity). The air supplementation was stopped and there was no water change for all the fish groups. The fish were fed with the same diet for each group at a rate $3 \%$ of live body weight daily. The temperature and $\mathrm{pH}$ of the water were measured three times daily. This experiment lasted for 4 days (96 hours). During this experimental period the fish behavior was recorded. At the end of the treatment, the fish from each aquarium were weighed and measured for the total length. The gonads, liver and spleen indices were calculated as above mentioned. Blood samples were collected from each fish by the same above mentioned method. Moreover, the hemoglobin and hematocrit levels were estimated according to the same method above mentioned. Serum samples were obtained as above mentioned and stored under $-20 \mathrm{C}^{\mathrm{o}}$. The serum was stored for determination of the total protein, albumin, alkaline phosphatase, and glucose by the same above mentioned methods. Body indices (HSI, SSI and GSI) were calculated as above shown.

\section{Statistical analysis}

The obtained data were subjected to statistical analysis using one-way ANOVA according to the following model:

$$
Y_{i j}=\mu+T_{i}+E_{i k}
$$

Where: $Y_{i j}=$ an observation, $\mu=$ overall mean, $T_{i}=$ effect of treatment, and $E_{i k}=$ random error.

Differences among means of the experimental groups were tested for significance by Duncan's multiple range tests (Duncan, 1955). Differences were considered significant when $\mathrm{P} \leq 0.05$.

\section{RESULTS AND DISCUSSION}

\section{1- Growth performance}

Body weight (BW) and body weight gain (BWG)

The presented data in Table (2) showed that the average body weight at the start of the experiment for all groups [control (C), 1\% $\mathrm{N}$. sativa (T1), $2 \% N$. sativa (T2), was 101.36, having not significant differences in between.

At the second week of the experiment there was insignificant differences between the treatments and control ones; it increased for $\mathrm{T}_{1}$ by $0.58 \%$. Also, the results in Table (3) showed that the averages of body weight gain were 14.80 and 12.91 for T1 and T2 versus 13.53 for the control group at the second week. Also, the results showed that treated groups had insignificant $(P>0.05)$ higher ABWG compared to the control group. 
Table (2): Average body weight \pm SE of Oreochromis niloticus treated with different levels of Nigella sativa.

\begin{tabular}{lccccccc}
\hline \multirow{2}{*}{ Treatments } & \multicolumn{7}{c}{ Experiment weeks } \\
\cline { 2 - 8 } & 0 & 2 & $\mathbf{4}$ & $\mathbf{6}$ & $\mathbf{8}$ & $\mathbf{1 0}$ & $\mathbf{1 2}$ \\
\hline \multirow{2}{*}{ Control } & 101.67 & 115.20 & 126.07 & 145.33 & 152.53 & 176.61 & 182.11 \\
& \pm 2.55 & \pm 3.12 & \pm 3.52 & \pm 4.29 & \pm 4.08 & \pm 5.04 & \pm 5.25 \\
\hline \multirow{2}{*}{$\mathrm{T} 1(1 \% \mathrm{NS})$} & 101.07 & 115.87 & 126.13 & 145.96 & 144.6 & 172.15 & 183.9 \\
& \pm 2.64 & \pm 2.70 & \pm 2.94 & \pm 3.44 & \pm 3.76 & \pm 4.14 & \pm 4.64 \\
\hline \multirow{2}{*}{$\mathrm{T} 2(2 \% \mathrm{NS})$} & 102.16 & 115.07 & 130.09 & 145.18 & 155.79 & 180.12 & 196.44 \\
& \pm 2.34 & \pm 2.68 & \pm 3.28 & \pm 3.43 & \pm 3.27 & \pm 4.92 & \pm 5.55 \\
\hline
\end{tabular}

At the fourth week, the average body weight increased insignificantly $(\mathrm{P}>0.05)$ for T1 and T2, as compared with control ones. At the sixth week of the experiment, the average body weight for the same groups (C, T1 and T2) were 145.33and 145.96, and 145.18, respectively (Table 2).

Also, the fish groups fed $2 \% N$. sativa had ABWG insignificant $(P>0.05)$ differences as compared with the control group (Table $3)$.

Table (3): Average body weight gain of Oreochromis niloticus treated with different levels of Nigella sativa

\begin{tabular}{|c|c|c|c|c|c|c|c|c|}
\hline \multirow{2}{*}{\multicolumn{2}{|c|}{ Treatments }} & \multicolumn{6}{|c|}{ Experimental weeks } & \multirow{2}{*}{$\begin{array}{c}\text { Overall } \\
\text { Mean } \\
\end{array}$} \\
\hline & & 2 & 4 & 6 & 8 & 10 & 12 & \\
\hline Control & & 13.53 & 10.87 & 19.26 & 6.2 & 24.08 & $5.5^{\mathrm{a}}$ & 13.24 \\
\hline \multirow{2}{*}{$\begin{array}{l}\text { Nigella } \\
\text { sativa }\end{array}$} & $\mathrm{T} 1(1 \%)$ & 14.8 & 10.26 & 19.83 & -1.36 & 27.55 & $11.75^{\mathrm{b}}$ & 13.81 \\
\hline & $\mathrm{T} 2(2 \%)$ & 12.91 & 15.02 & 15.09 & 10.61 & 24.33 & $16.32^{\mathrm{b}}$ & 15.71 \\
\hline
\end{tabular}

Means with different superscripts in the same row are significantly different $(\mathrm{P} \leq 0.05)$.

On the sixth week, the supplementation of $1 \% N$. sativa maximized the average body weight gain. At the eighth week the average body weight increased insignificantly $(\mathrm{P}>$ 0.05 ) for $\mathrm{T} 2$ only where it increased by 2.14 $\%$ as compared with control ones (Table 2 ). Moreover, the body weight gain of the treated fish at the eighth week for the fish groups treated with $2 \% \mathrm{~N}$. sativa increased by $71.13 \%$ compared with the control group.

At the tenth week and the twelfth week, the average body weight there for the groups (T1 and T2) and analysis of variance for body weight at these periods showed that there were insignificant $(P>0.05)$ differences compared to the controls. At tenth week the body weight gain for the same groups were $24.08,27.55$ and $24.33 \mathrm{~g}$ (Table 3) for $\mathrm{C}, \mathrm{T} 1$ and $\mathrm{T} 2$, respectively. While, at the twelfth week, the body weight gain for the same groups treated with $1 \%$ and $2 \% N$. sativa had a significant $(\mathrm{P} \leq$ $0.05)$ increase compared with control ones (Table 3).

Moreover, at the end of the experimental period the overall mean averages of body weight for the groups were 142.79, 141.38 and 146.41, and AVBWG were 13.24, 13.81 and 15.71 for control, T1 and T2, respectively (Table 2,3 ).

However, the obtained results showed that the level of $N$. sativa (1\% and $2 \%$ ) had insignificant $(P>0.05)$ effect on body weight of Nile tilapia (Oreochromis 
niloticus) all over the experimental period. These results are supported by Dey et al. (2020), who concluded that dietary $2 \% \mathrm{~N}$. sativa did not significantly change the body weight and body weight gain in $O$. niloticus when compared to the control. Also, Bektaş et al. (2018) showed that there were no significant differences among the fish group fed on $2.5 \mathrm{~g} / \mathrm{k} N$. sativa and control. In the same trend, Al-Dubake et al. (2012) declared that the diet containing $1 \%$ black seed improved insignificantly $(\mathrm{P}>0.05)$ growth rate compared with control and diet containing 3\% N. sativa in cyprinus carpio. Some researchers attributed the relative increase in BW and BWG of Nile tilapia fed on Nigella sativa seeds to its digestive stimulating effect through their aromatic substances or essential oils (Abou-Zeid, 1998).
Bilen et al. (2011) didn't acquire any significant increase in growth rate and average weight due to $N$. sativa supplementation. In another study, John et al. (2007) used 3\% N. sativa on the growth of Oreochromis niloticus, and the observed mean final weight in the treatment was higher than the control. In Red tilapia, Abd Elmonem et al. (2002) found that dietary addition of black seed (Nigella sativa) at levels $0,3,6$ and $9 \%$ displayed positive effects on growth performance.

\section{2- Body length (BL):}

The differences in body length among the experimental groups were insignificant $(P$ $>$ 0.05) (Table 4), which indicate that experimental groups were homogenous at the beginning of the experiment.

Table (4): Average body total length \pm SE (cm) of Oreochromis niloticus treated with different levels of Nigella sativa for 12 weeks

\begin{tabular}{ccccccccc}
\hline & \multicolumn{7}{c}{ Experiment period (weeks) } \\
\cline { 2 - 8 } Treatments & $\mathbf{0}$ & $\mathbf{2}$ & $\mathbf{4}$ & $\mathbf{6}$ & $\mathbf{8}$ & $\mathbf{1 0}$ & $\mathbf{1 2}$ \\
\hline \multirow{2}{*}{ Control } & $17.97 \pm$ & 18.90 & 19.96 & 20.37 & 20.78 & 21.39 & 21.98 \\
Nigella & 0.16 & \pm 0.21 & \pm 0.16 & \pm 0.2 & \pm 0.20 & \pm 0.20 & \pm 0.21 \\
\cline { 3 - 9 } sativa & & 18.13 & 18.82 & 19.68 & 20.44 & 20.49 & 21.19 & 21.92 \\
& & $\pm 0.16^{\mathrm{a}}$ & $\pm 0.14^{\mathrm{a}}$ & $\pm 0.13^{\mathrm{a}}$ & $\pm 0.15^{\mathrm{a}}$ & $\pm 0.17^{\mathrm{b}}$ & $\pm 0.17^{\mathrm{a}}$ & $\pm 0.18^{\mathrm{a}}$ \\
\hline & & 18.28 & 19.04 & $20.01 \pm$ & 20.34 & 21.9 & 21.68 & 22.33 \\
& $\mathbf{T 2}(\mathbf{2 \%})$ & \pm 0.15 & \pm 0.15 & 0.18 & \pm 0.17 & \pm 0.14 & \pm 0.18 & \pm 0.19 \\
\hline
\end{tabular}

Means with different superscripts in the same row are significantly different $(\mathrm{P} \leq 0.05)$.

Table (5): Average length increment \pm SE $(\mathrm{cm})$ of Oreochromis niloticus treated with different levels of Nigella sativa for 12 weeks

\begin{tabular}{ccccccccc}
\hline & \multicolumn{8}{c}{ Period (weeks) } \\
\cline { 2 - 9 } Treatments & $\mathbf{2}$ & $\mathbf{4}$ & $\mathbf{6}$ & $\mathbf{8}$ & $\mathbf{1 0}$ & $\mathbf{1 2}$ & $\begin{array}{c}\text { Overall } \\
\text { Mean }\end{array}$ \\
\hline Control & 1.04 & 0.95 & 0.41 & 0.65 & 0.63 & 0.58 & 0.87 \\
\hline \multirow{2}{*}{ Nigella sativa } & $\mathbf{T 1}(\mathbf{1 \% )}$ & 0.69 & 0.85 & 0.77 & 0.01 & 0.74 & 0.37 & 0.57 \\
\cline { 2 - 9 } & $\mathbf{T 2}(\mathbf{2 \%})$ & 0.77 & 1.01 & 0.28 & 0.59 & 1.28 & 0.65 & 0.76 \\
\hline
\end{tabular}

After two weeks the analysis of variance for the body length and length increment showed that there were no significant $(\mathrm{P}>$
0.05) differences between the treatment groups and control ones. On the fourth and six week of the experiment the average 
body length for T2 only increased by $0.25 \%$ versus the control ones (Table 4). While, there were insignificant $(P>0.05)$ differences in body length and length increment compared with control ones. On the sixth, eighth, tenth and twelfth week no significant $(P>0.05)$ differences in body length and length increment for all groups comparing with the control ones. These results are in coincided with Bektaş et al. (2018) who showed that there was insignificant $(\mathrm{P}>0.05)$ differences in length between groups fed dietary $N$. sativa.

\section{Hepato, gonado and spleeno - somatic} indices:

Data presented in Table (6) showed that the, dietary $1 \% N$. sativa decreased hepatosoatic index (HSI) insignificantly $(P>0.05)$, while, $2 \% \mathrm{~N}$. sativa increased it insignificantly $(P>0.05)$. Also, the dietary 1 and $2 \% \quad N$. sativa has effects on spleenosomatic index (SSI) compared to groups control ones. Also, the gonadosomatic index for male (MGSI) decreased insignificantly $(P>0.05)$ in T1 and T2 as compared with control group.

Table (6): Average hepato, gonado and spleeno - somatic indices \pm SE. of $O$. niloticus fed dietary Nigella sativa for 12 weeks.

\begin{tabular}{lccc}
\hline \multirow{2}{*}{ Treatment } & \multicolumn{2}{c}{ Control } & \multicolumn{2}{c}{ Nigella sativa } \\
\cline { 2 - 4 } & \multicolumn{1}{c}{$\mathbf{C}$} & $\mathbf{T 1}(\mathbf{1 \% )}$ & $\mathbf{T}$ (2\%) \\
\hline HSI & $1.41 \pm 0.15$ & $1.33 \pm 0.09$ & $1.83 \pm 0.08$ \\
\hline SSI & $0.10 \pm 0.01$ & $0.11 \pm 0.02$ & $0.11 \pm 0.01$ \\
\hline Male GSI & $0.46 \pm 0.12$ & $0.44 \pm 0.12$ & $0.35 \pm 0.08$ \\
\hline
\end{tabular}

\section{4- Blood parameters:}

\section{A- Hematological parameters:}

Hemoglobin level was insignificantly increased $(P>0.05)$ for $\mathrm{T} 1$ and $\mathrm{T} 2$ as compared with the control group. The hematocrit (PCV \%) increased insignificantly $(P>0.05)$ in fish group fed $2 \% N$. sativa (T2) as compared with the control group.

These results are in harmony with Bektaş et al. (2018) who recorded that higher HCT levels were found at doses of $0.5,2.5$ and $10.0 \mathrm{~g} / \mathrm{kg}$ N. sativa. Also, John et al. (2007) recorded significant hematocrit values in $O$. niloticus fed with $3 \% N$. sativa.

Means with different superscripts in the same row are significantly different $(\mathrm{P} \leq 0.05)$.

\section{B- Serum constituents:}

The achieved results illustrated in Table (7) showed that dietary supplementation with $N$. sativa displayed higher serum total protein $(P>0.05)$ in T2 than T1. However, such increase in total protein was mainly due to the increase in the globulin concentration rather than albumin. This increase in serum total protein supported the higher growth of T2 fishes (Table 7).

These results were supported by Yang and Chen (2003) who mentioned that total serum protein is one of the most important indicators of general health of fish. Also, Ahmed and Ali (2013) reported that the total protein concentration in fish serum differ, depending on a series of factors such as food diet, species, season, degree of sexual maturity and water temperature. Awad et al. (2013), reported an enhancement in total protein and lysozyme activity in groups fed with $N$. sativa oil and Quercetin, especially with higher doses that recorded the highest significant value compared to the controls. 
Table (7): The average blood components \pm S.E (hematological parameters) and serum variables of $O$. niloticus fed dietary Nigella sativa for 12 weeks

\begin{tabular}{|c|c|c|c|c|}
\hline \multirow[b]{2}{*}{ Variables } & & \multicolumn{3}{|c|}{ Treatments } \\
\hline & & Control & $\begin{array}{l}\text { T1. } 1 \% \quad N . \\
\text { sativa }\end{array}$ & T1. $2 \%$ N. sativa \\
\hline $\begin{array}{l}\text { Blood components } \\
\text { a) Hematology } \\
\text { 1) Hemoglobin }(\mathrm{g} / \mathrm{dl})\end{array}$ & & $7.63 \pm 0.43$ & $8.81 \pm 0.37$ & $8.88 \pm 0.47$ \\
\hline 2) Hematocrit (\%) & & $28.75 \pm 1.04^{\mathrm{a}}$ & $24.40 \pm 1.23^{\mathrm{b}}$ & $29.50 \pm 1.44^{\mathrm{a}}$ \\
\hline $\begin{array}{l}\text { b) Serum constituents } \\
\text { 1- Total protein }(\mathrm{g} / \mathrm{dl})\end{array}$ & & $6.03 \pm 0.51$ & $5.77 \pm 0.42$ & $5.68 \pm 0.34$ \\
\hline 2- Albumin (g/dl) & & $4.02 \pm 0.47$ & $4.42 \pm 0.27$ & $4.61 \pm 0.34$ \\
\hline 3- Globulin (g/dl) & & $2.01 \pm 0.83$ & $1.35 \pm 0.40$ & $1.07 \pm 0.32$ \\
\hline 4- Alkaline phosphatase & $(\mathrm{U} / \mathrm{I})$ & $89.63 \pm 8.34^{\mathrm{c}}$ & $103.90 \pm 2.44^{\mathrm{b}}$ & $133.50 \pm 3.98^{\mathrm{a}}$ \\
\hline 7- Glucose (mg \%) & & $113.40 \pm 55.97^{\mathrm{b}}$ & $162.52 \pm 31.27^{\mathrm{a}}$ & $159.94 \pm 26.79^{\mathrm{a}}$ \\
\hline
\end{tabular}

The results in Table (7) showed that the supplementation with $1 \%$ and $2 \% N$. sativa had significantly $(P<0.05)$ higher alkaline phosphatase activity as compared with control the fish group. It is clear that the alkaline phosphatase increased in the case of high level of $N$. sativa $(2 \%)$ where it increased by $48.95 \%$ as compared with the control ones.

The present results agree with the findings of Wache et al. (2006) who found that feeding trout on $S$. cerevisiae led to significant $(P<0.05)$ higher activity of alkaline phosphatase. They attributed this increase to the earlier maturation of digestive system in fish. In addition, TovarRamíreza et al. (2004) reported that the probiotics stimulated amylase secretion and the activity of alkaline phosphatase in larval sea bass. The dietary $N$. sativa resulted in a significant $(P<0.05)$ decrease in the serum glucose concentrations by 44.13 and $52.14 \%$ for $1 \%$ and $2 \% N$. sativa as compared with the control ones. These findings are coincided with findings of AlDubakel et al. (2012) who showed that blood glucose of common carp fed different experimental diets $(0,1$, and $3 \% N$. sativa $)$ were significantly different $(\mathrm{P}<0.05)$ between control and diet; the $3 \% N$. sativa treatment sowed higher blood glucose versus those of the control and $1 \%$ treatment $(120.88 \mathrm{~mm} / \mathrm{dl}$ versus 67.66 and $75.33 \mathrm{~mm} / \mathrm{dl}$ ). However, most authors concluded that fish behave like diabetic mammals with respect to blood glucose (Hepher, 1988).

\section{The effect of dietary $N$. sativa on Nile tilapia on behavioral changes under oxygen deficiency}

At the beginning of the experiment, the control fish exhibited remarkable decreased activity. Also, increased random movement elicited by hypoxia changes in direction of swimming. The fish groups fed diets with $N$. sativa showed slightly abnormal behavior changes due to reduction of dissolved oxygen. These signs were reported by Doudoroff and Shumway (1970). Moreover, the control fish group exhibited remarkable signs of distress, including fast swimming, erratic movement, great surfacing frequency to gulp atmospheric air, loss of body equilibrium and decreased attention to the 
feeding. At the end, the fish died with opened mouth.

In contrast, fish groups maintained at the same condition of oxygen deficiency and supplemented with dietary $N$. sativa showed less above-mentioned abnormal behavior than the control group. Such response to oxygen deficiency may be due to increase of respiration rate and heart rate (Dheer, 1988; Mason, 1991). Also, reduction of water dissolved oxygen content which may be attributed to the inhibiting effect of photosystems $I$ and $\Pi$ and community respiration (Ojala, 1966).

The improvement of dietary $N$. sativa on Nile tilapia (Oreochromis niloticus) behavior under oxygen deficiency may supported by Chanock et al. (1994) who reported that phagocyte activation is usually associated with abrupt rise in oxygen consumption, leading to production of reactive oxygen species (ROS) which play an important role in the host defense. This metabolic event is called the respiratory burst and the main enzyme involved in this process is an $\mathrm{NADP}^{+}$oxidase. The respiratory burst activity of fish phagocytes can be modulated in vivo and in vitro by many substances (Tahir and Secombes, 1996), glucans (Couso et al., 2001), levamisole (Mulero et al., 1998) and animal extracts (Bøgwald et al., 1996). Li and Gatlin (2003) found that feeding juvenile hybrid striped bass a diet supplemented with growth promotion for 16 weeks increased blood neutrophil oxidative radical production and extracellular superoxide anion production of head kidney leucocytes.

\section{Effects on mortality rate under oxygen defficiency:}

The mortality rate of Oreochromis niloticus exposed to oxygen deficiency was 100,40 and 20 for control, T1 and T2, respectively. It is clear that dietary $(1 \%$ and $2 \%) \mathrm{N}$. sativa had significant effect on survival rate of $O$. niloticus under oxygen deficiency where the mortality rate was 40 and 20 , for $\mathrm{T} 1$ and $\mathrm{T} 2$, as compared with $100 \%$ for control group. For these, Khondoker et al. (2016) used Nigella sativa at 2\%,4\% and $6 \%$ doses and investigated immunological parameters such as bactericidal activity and phagocytic activity. For the role of $N$. sativa on mortality rate of $O$. niloticus under oxygen deficiency; it was obvious that high level $(2 \%)$ of $N$. sativa has significant $(P<$ 0.05 ) effect on mortality rate where it reduced the mortality rate, from $100 \%$ in the control to $20 \%$ in $2 \% N$. sativa (T2). While, the treatment received low level (1\%) of $N$. sativa (T1) showed high mortality rate $(40 \%)$.

Moreover, the positive role of $N$. sativa in reduction of mortality rate in the fish is supported by some studies, as that of Dorucu et al. (2009) who used 1\%, 2.5\% and $5 \%$ of $N$. sativa on the immune response of $O$. mykiss and they found higher serum protein levels $(\mathrm{P}<0.05)$ higher than the controls. Survival rate was improved and all treatments showed no mortality all over the experimental period (Al-Dubakel, 2012). Moreover, black seed (Nigella sativa) enhanced $\mathrm{T}$ cell immunity and production of cytokines (Haq et al., 1995), and natural killer cell and compliment (Mahdi, 1993). Also, Nigella sativa extract has positive effect on leukocytes (Mona et al., 2002). In the same trend, Diab et al. (2008) argued that it could increase the survival rate and the resistance of fish to some infectious diseases and may enhance the growth performance especially after prolonged application.

Similarly, Bektaş et al. (2018) reported that the application of medicinal plants and their derivates as immunostimulants in fish culture is an effective and safe method to enhance the immune responses against pathogens during periods of stress, such as intensive farming culture, grading, vaccination and reproduction. 


\section{7- Blood components:}

\section{A-Hematological parameters:}

Hemoglobin (Table 8) levels did not significantly $(P>0.05)$ alter by oxygen deficiency for all the fish groups. While, the hematocrit (PCV\%) levels increased significantly $(\mathrm{P}<0.05)$ in $\mathrm{T} 2$ as compared with T1.The improvement in hemoglobin and hematocrit levels due to dietary probiotics may be due to their improvement of the spleen status as SSI (Table 9) which is the main organ for the processing, storing and maturing of the erythrocytes.
Similar results were found by Hussein and Kobeisy (1999) on the same fish $(O$. niloticus) who reported that oxygen deficiency led to increase of hemoglobin and hematocrit. Tun and Houston (1986) attributed these results to the stimulating effect of oxygen deficiency on red blood cells liberation from spleen and subsequently erythropoiesis.., Abdelhamid (2006) reported that hypoxia was responsible for increased PCV $\%$ and decreased $\mathrm{Hb}$ in $O$. niloticus.

Table (8): Average blood components (hematological parameters and serum constituents) of Nile tilapia (Oreochromis niloticus) under stress factors (Oxygen deficiency) \pm S.E

\begin{tabular}{llll}
\hline & \multicolumn{3}{c}{ Treatments } \\
\cline { 2 - 4 } Variables & Control & T1.1\% N. sativa & T1.2\% N. sativa \\
\hline
\end{tabular}

Blood components

\begin{tabular}{llcc}
$\begin{array}{l}\text { a) Hematology } \\
\text { 1) Hemoglobin }(\mathrm{g} / \mathrm{dl})\end{array}$ & N.D. & $8.80 \pm 35$ & $8.86 \pm 46$ \\
\hline 2) Hematocrit \% & N.D. & $23.40 \pm 1.23^{\mathrm{b}}$ & $30.51 \pm 1.44^{\mathrm{a}}$ \\
\hline $\begin{array}{l}\text { b) Serum constituents } \\
\text { 1- Total protein }(\mathrm{g} / \mathrm{dl})\end{array}$ & N.D. & $3.80 \pm 36^{\mathrm{b}}$ & $6.40 \pm 82^{\mathrm{a}}$ \\
\hline 2- Albumin $(\mathrm{g} / \mathrm{dl})$ & N.D. & $9.93 \pm 48^{\mathrm{a}}$ & $4.58 \pm 33^{\mathrm{b}}$ \\
\hline 3- Globulin $(\mathrm{g} / \mathrm{dl})$ & N.D. & $1.33 \pm 0.40^{\mathrm{b}}$ & $3.04 \pm 0.35^{\mathrm{a}}$ \\
\hline & N.D. & $103.90 \pm 2.42^{\mathrm{b}}$ & $132.48 \pm 3.96^{\mathrm{a}}$ \\
\hline 4- Alkaline phosphatase (U/I) & N.D. & $158.91 \pm 23.79$ & $160.50 \pm 30.26$ \\
\hline 7- Glucose $(\mathrm{mg} \%)$ & N.c
\end{tabular}

N.D : not determined according to dying of all fish in control group after one day.

Means with different superscripts in the same row are significantly different $(\mathrm{P} \leq 0.05)$.

\section{B- Serum constituents}

Serum total protein concentration tended to be significant $(P<0.05)$ higher in fish groups fed dietary $2 \% N$. sativa. Such increase in total protein levels mainly due to the increase of serum globulin rather than albumin concentration (Table 8). In fact, the improvement of globulin level in fish groups fed dietary $N$. sativa may attributed to immune system response under oxygen deficiency. These results are supported by Hussein and Kobeisy (1999) who found similar results in $O$. niloticus. Also, Shul'man (1974) stated the same results.
Serum alkaline phosphatease activity was significantly increased $(P<0.05)$ for the fish groups T2 as compared with the T1. The increase in alkaline phosphatase of $O$. niloticus fed dietary $N$. sativa may be throughout their effects on immune response and counteracting the adverse effect of oxygen deficiency. However, these results are confirmed by some researchers such as Wilson (1973) and Lovell and Lim (1978), who reported that the increase of serum alkaline phosphatase activity coincided with the elevation of some antistress supplementation. 
Serum glucose concentration did insignificantly $(P>0.05)$ affected due to oxygen deficiency. This result may be attributed to the physiological role of $N$. sativa on decreasing glucocorticoids synthesis. These results are in harmony with those found by Thaxton and Pardue (1984) and consequently gluconeogenesis. Moreover, Abdelhamid (2006) recorded highly significant increase in plasma glucose and significant decrease in plasma total protein in tilapia suffered from hypoxia for 3 days.

\section{C- Hepato, gonado and spleeno-somatic indices}

Data presented in Table (9) showed that there were insignificant $(P>0.05)$ differences in hepatosomatic (HSI) index of $O$. niloticus under oxygen deficiency for $\mathrm{T} 1$ and $\mathrm{T} 2$. These results are coincided with the findings of Hussein and Kobeisy (1999), who reported that HSI of the same fish $(O$. niloticus) was not affected by oxygen deficiency. Also, the present results are in harmony with the findings of Hussein and Kobeisy (1999), which indicated that $O$. niloticus exposed to oxygen deficiency had higher SSI than the controls. They attributed this increase in SSI to the reduction in the concentration of plasma corticosterone. Moreover, Halver (1985) reported that the high level of corticosterone led to a prominent decrease in spleen size. In addition, this improvement in SSI is attributable to acceleration of iron absorption in the spleen. However, it could refer the improvement in SSI of O. niloticus fed $1 \%$ $N$. sativa to their content of some enzymes and protein which may improve the immune response.

There were significant differences $(P<$ $0.05)$ in gonadosomatic index among the fish fed groups $1 \%$ and $2 \% N$. sativa. The significant $(P<0.05)$ increase in GSI may be due to the improvement effect on fish appetite and increase the energy intake which is required for reproduction (Spieler et al., 1977). Moreover, the dietary supplementation counteracted insignificantly the adverse effects of oxygen deficiency on GSI may be through its stimulative effect in biosynthesis of sex steroids (Levine and Morita, 1985).

To conclude the results, the dietary supplementation with N. sativa at 1 and $2 \%$ displayed slight beneficial effects on growth performance and major beneficial effects on some blood constituents of $O$. niolticus. In point of view, additionally, $N$. sativa has high potent on immunity of $O$. niloticus.

Table (9): Average hepato, spleeno and gonado - somatic indices of Nile tilapia (Oreochromis niloticus) under stress factors (Oxygen deficiency) \pm S.E. for different treatment at experimental period

Treatments

Variables

Control $\quad(1 \%$ N. sativa $) \mathrm{T} 1 \quad(2 \%$ N. sativa $) \mathrm{T} 2$

\begin{tabular}{cccc}
\hline HSI & N.D. & $1.39 \pm 0.11$ & $0.41 \pm 0.06$ \\
\hline SSI & N.D. & $0.17 \pm 0.08$ & $0.08 \pm 0.00$ \\
\hline GSI & N.D. & $0.56 \pm 0.12^{\mathrm{b}}$ & $1.49 \pm 0.21^{\mathrm{a}}$ \\
\hline
\end{tabular}

N.D.: Not determine 


\section{REFERENCES}

Abd Elmonem, A.; S.M.M. Shalaby and El Dakar, A.Y. (2002): Response of red tilapia to different levels of some medicinal plants by-products black seed and roquette seed meal. Proceeding, of the 1st Scientific Conference on Aquaculture 13-15 December 2002, El Arish, Egypt.

Abdel-Fattah, M. and El-Sayed (Edts.) (2006): Tilapia culture. CABI Publishing, Cambridge, p. 304. https://www.cabi.org/bookshop/book/ 9780851990149/. Accessed 5 Mar 2020

Abdel-Ghaffar, FA.; El-Feki, MA.; Faheem, HI. and Gad, MA. (2003): Potentiating effects of some natural products on the common carp immune system against Aeromonas hydrophila. J. Aquat Biol Fish 7: 2347.

Abdelhamid, A.M. (2006): Hemolytic activity in blood serum of Orochromis niloticus under different typs of stress. The $3^{\text {rd }}$. Int. Conf. for Develop. And the Env. In the Arab world, March, 21-23, pp: 153-169.

AbouZied, R.M. (1998): Evaluation of some medicinal plants as a feed additive in diets of Nile tilapia (Oreochromis niloticus). M.Sc., Faculty of Agriculture, El-Fayoum, Cairo University.

Ahmad, A.; Husain, A.; Mujeeb, M.; Khan, S.A.; Najmi, A.K.; Siddique, N.A.; Damanhouri, A.Z. and Anwar, F. (2013): A review on therapeutic potential of Nigella sativa: A miracle herb. Asian Pacific Journal of Tropical Biomedicine, 3(5), 337-352.

Ahmed, S.M. and Ali, A.H. (2013): Serum proteins and leucocytes differential count in the common carp (Cyprinus carpio L.) infested with ectoparasites. Mesopotamian Journal of Marine Science, 28(2), 151-162.

Al-Dubakel, A.Y.; Al-Mhawe, B.H.; Majeed, M.F. and Shaeyal, L.W. (2012):
Preliminary study on the effect of dietary black seed (Nigella sativa) on growth and blood glucose of common carp (Cyprinus carpio) fingerlings. Thi-Qar University Journal for Agricultural Researches, 2(2222-5005), pp.41-51.

Atta, M.B. (2003): Some characteristics of nigella (Nigella sativa L.) seed cultivated in Egypt and its lipid profile. Food Chemistry, 83, 63-68.

Awad, E.; Austin, D. and Lyndon, R.A. (2013): Effect of black cumin seed oil (Nigella sativa) and nettle extract (Quercetin) on enhancement of immunity in rainbow trout, Oncorhynchus mykiss (Walbaum). Aquaculture. 388-391, 193-197.

Bektaş, Z.H.; Savaşer, S.; Akçimen U.; Ceylan, M.; Yener, $O$. and Bulut, $C$. (2018): Using of Black Cumin Seed Powder (Nigella sativa) as Immunostimulant and Growth Promoter in Rainbow Trout, Oncorhynchus mykiss (Walbaum). Turk. J. Fish.\& Aquat. Sci. 19(12), 987-999 http://doi.org/10.4194/13032712-v19_12_01

Bilen, S.; Bulut, M. and Bilen, A.M. (2011): Immunostimulant effects of Cotinus coggyria on rainbow trout (Oncorhynchus mykiss). Fish and Shellfish Immunolgy, 30,451-455. https://doi.org.10.1016/j.fsi.2010.12.0 13.

Bøgwald, J.; Dalmo, R.A.; Leifson, R.M.; Stenberg, E. and Gildberg, A. (1996): The stimulatory effect of a muscle protein hydrolysate from Atlantic cod, Gadus morhua L., on Atlantic salmon, Salmo salar L., head kidney leucocytes. Fish Shellfish Immunol. 6: 3-16.

Bulfon, C.; Volpatti, D. and Galeotti, M. (2013): Current research on the use of plant-derived products in farmed fish. Aquaculture Research, 46 (3).

Chanock, S.J.; El Benna, J.; Smith, R.M. and Babior, B.M. (1994): The 
respiratory burst. J. Biol. Chem. 269: 24519- 24522.

Chervinski, J. (1982): Environmental physiology of tilapias. In: Pullin RSV, Lowe-McConnell RH (Edts.), The biology and culture of tilapias. ICLARM conference proceedings 7 , International Center for Living Aquatic Resources Management, Manila, Philippines, pp. 119-128.

Couso, N.; Castro, R.; Noya, M.; Obach, A. and Lamas, J. (2001): Location of superoxide production sites in turbot neutrophils and gilthead seabream acidophilic granulocytes during phagocytosis of glucan particles. Dev. Comp. Immunol. 25: 607-618.

Dey, B.K.; Hossain, M.M.M. and Alam, M.E. (2020): Effect of black cumin seed oil on growth, innate immunity and resistance against Pseudomonas fluorescens infection in Nile tilapia Oreochromis niloticus. Aquaculture International, 1-15.

Dheer, G.M.S. (1988): Hematological, hematopoietic and biochemical responses to thermal strees in an airbreathing freshwater fish, Channa punctaus Bloch. J. Fish Biol., 32: 197-206.

Diab, A.S.; Salah, M.A.; George, J.; Yasser, A.H. and Mohamed, F.M. (2008): Effect of garlic, black seed and Biogen as immunostimulants on the growth and survival of Nile tilapia, Oreochromis niloticus (Teleostei: Cichlidae), and their response to artificial infection with Pseudomonas fluorescens. African Journal of Aquatic Science, 33(1): 63-68.

Dorucu, M.; Colak, S.; Ozesen, S.; Ispir, U.; Altinterim, B. and Celayir, $Y$. (2009): The Effect of Black Cumin Seeds, Nigella sativa, on the Immune Response of Rainbow Trout, Oncorhynchus mykiss. Mediterranean Aquaculture Journal, 2(1), 27-33.

Doudoroff, P. and Shumway, D.L. (1970): Dessolved oxygen requirments of frishwater fishes. FAO fish. Tech. Pap., (86). 291p.

Duncan, D.B. (1955): Multiple range and multiple F tests. Biometrics, 11(1), 142.

El-Dakar, A.Y.; Hassanien, G.D.; Gad, S.S. and Sakr, S.E. (2008): Use of dried basil leaves as a feeding attractant for hybrid tilapia, Oreochromis niloticus $\mathrm{X}$ Oreochromis aureus, fingerlings. Mediterranean Aquaculture Journal, 1(1); 35- 44.

FAO, (2016): The State of World Fisheries and Aquaculture Opportunities and Challenges. Food and Agriculture Organization of the United Nations, Rome, Italy (20164).

$F A O$, (2018): The state of world fisheries and aquaculture 2018-meeting the sustainable development goals. Food and Agriculture Organization of United Nations, Rome, pp. 1-210. http://www.fao.org/3/i9540en/i9540e n.pdf. Accessed 5 Mar 2020.

Gibtan, A.; Getahun, A. and Mengistou, S. (2008): Effect of stocking density on the growth performance and yield of Nile tilapia [Oreochromis niloticus (L., 1758)] in a cage culture system in Lake Kuriftu, Ethiopia. Aquac Res 39:1450-1460. https://doi.org/ 10.1111/j.1365-2109.2008.02021.x

Haq, A.; Abdullatif, M.; Lobo, P.; Khabar, $K$.; Sheth, $K$. and Alsedairy, $S$. (1995): Nigella sativa effect on human lymphocytes and polymorphonuclear leucocytes phagocytic activity. Immunopharmacol., 30 (2): 147-155.

Hepher, B. (1988): Nutrition of pond fishes. Cambridge Univ. press. 338 pp.

Hussein, S.Y. and Kobeisy, M.A. (1999): Enfelunce of heat strees on groweth performance and some blood constituents of Oreochromis niloticus fed ascorbic acid. Assuit Veterinary Medical J. 41 (8): 17-33.

John, G.; Mesalhy, S.; Rezk, M.; El Naggar, G. and Fathi, M. (2007): Effect of some immunostimulants as 
feed additives on the survival and growth performance of Nile tilapia, Oreochromis niloticus and their response to artificial infection. Egyptian Journal of Aquatic Biology and Fisheries, 11, 1299-1308.

Khondoker, S.; Hossain, M.M.M.; HasanUj-Jaman, M.; Alam, M.E.; Zaman, M.F.U. and Tabassum, N. (2016): Effect of Nigella sativa (Black Cumin Seed) to enhance the immunity of common carp (Cyprinus carpio) against Pseudomonas fluorescens. American Journal of Life Sciences, 4(3), 87-92.

Levine, M. and Morita, K. (1985): "Ascorbic acid in endocrine systems." Vitamins \& Hormones. Vol. 42. Academic Press, 1985. 1-64.

Li, P. and Gatlin, D.M. (2003): Evaluation of brewer's yeast (Saccharomyces cerevisiae) as a feed supplement for hybrid striped bass (Morone chrysops_M. saxatilis) Aquaculture 219; 681-692.

Lovell, R.T. and Lim, C. (1978): Vitamin C in pond diets for channel catfish. Trans. Am. Fish. Soc. 107: 321-325.

Mahdi, H. (1993): Effect of Nigella sativa $L$. on the immune system in cirrhotic patients. MDSc.

Mason, C.F. (1991): Biology of Freshwater Pollution. Second ed.Longman Sci., and Tech. pp. 187-194.

Mona, Z.; Rakha, G.; Osfor, M.; Bayumi, F. and Saad, M. (2002): Some clinicopathological and microbiological changes with hypercholestrimia in sheep and a trial of treatment with Nigella sativa and Titanium ascorbate. Bull. NRC., Egypt.

Mulero, V.; Esteban, M.A.; Muńoz, J. and Meseguer, J. (1998): Dietary intake of levamisole enhances the immune response and disease resistance of the marine teleost gilthead seabream (Sparus aurata L.). Fish \& Shellfish Immunol. 8: 49-62.
Ojala, O. (1966): Damage in fish caused by water pollution in Finland. Bull. Of Int EBIZ. 65 (5-6): 57 1- 582.

Ramíreza, T.D.; Infanteb, Z.J.; Cahub, C.; Gatesoupeb, F.J. and VázquezJuáreza, R. (2004): Influence of dietary live yeast on European sea bass (Dicentrarchus labrax) larval development. Aquaculture 234: 415427.

Shelton, W.L. (2002): Tilapia culture in the 21st century. In: Guerrero RD, Castillo MRG (Edts.), Tilapia farming in the 21st century. Philippine Fisheries Association, Laguna, pp. 120.

Shul'man, G.E. (1974): Life cycles of fish: Physiology and biochemistry. John Wiley, New York, NY, 258.

Spieler, R.E.; Noeske, T.A.; Devlaming, V. and Meier, A.H. (1977): Effects of thermocycles on body weight gain and gonadal growth in the goldfish, Carassius auratus. Transactions of the American Fisheries Society, 106(5), 440-444.

Stoskopf, M.K. (1993): Fish medicine. W.B. Saunders Company. Harcourt Brace Jovanovich. Toronto, Canada.

Tahir, A. and Secombes, C.J. (1996): Modulation of dab (Limanda limanda L.) macrophage respiratory burst activity. Fish \& Shellfish Immunol. 6: 135-146.

Thaxton, J.P. and Pardue, S.L. (1984): Ascorbic acid and physiological strees. In Tagweker, F.J., and Moustgaard, J. (Editors). Ascorbic acid in domestic animals: 25-31. Work shop Skjoldenaesholm, Septemper.

Tun, N. and Houston, A.H. (1986): Temperature, oxygen, photoperiod and the haemoglobin system of the rainbow trout, Salmo jairdneri. San. J. Zool., 64: 1883-1888.

Waché, Y.; Auffray, F.; Gatesoupe, F.; Zambonino, J.; Gayet, V.; Labbé, L. and Quentel, C. (2006): Cross effects of the strain of dietary 
Saccharomyces cerevisiae and rearing conditions on the onset of intestinal microbiota and digestive enzymes in rainbow trout, Onchorhynchus mykiss, fry. Aquaculture 258: 470478.

Wilson, R.P. (1973): Absence of ascorbic acid synthesis in channel catfish and blue catfish. Comp. Biochem. physiol. 46B,: 635-638.

Yang, J.L. and Chen, H.C. (2003): Effects of gallium on common carp
(Cyprinus carpio): acute test, serum biochemistry and erythrocyte morphology. Chemosphere, 53, 877882. http://doi.org.10.1016/S00456535(03)00657-X

Ziaee, T.; Moharreri, N. and Hosseinzadeh, H. (2012): Review of pharmacological and toxicological effects of Nigella sativa and its active constituents, Journal of Medicinal Plants, 2(42), 16-42.

\section{تأثثير بذور حبة البركة على أداء النمو وبعض مكونات الام للبطى النيلى \\ سعبي بيوسف حسين ، خالد أبو العز فؤاد محمد ، محمود الكيلاوى ، دعاء بيوسف أحدد}

Email: Samir.youssif@agr.au.edu.eg Assiut University web-site: www.aun.edu.eg

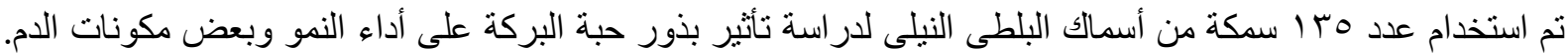

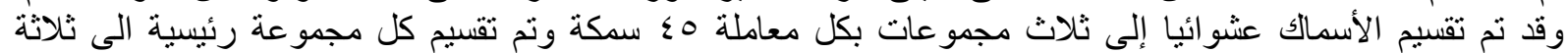

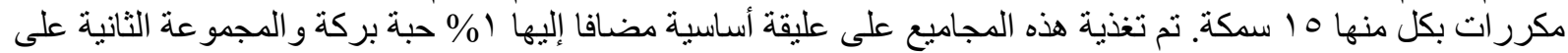

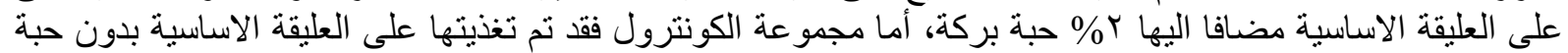

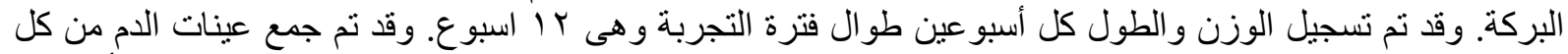

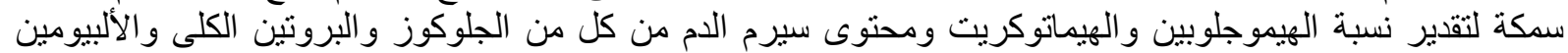

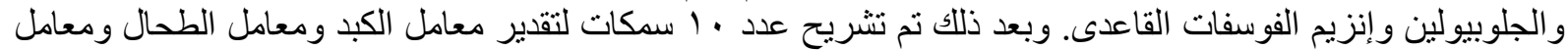

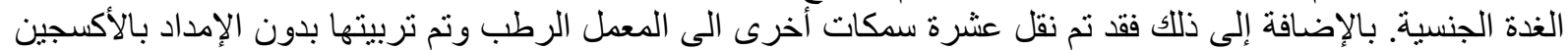

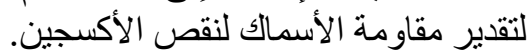

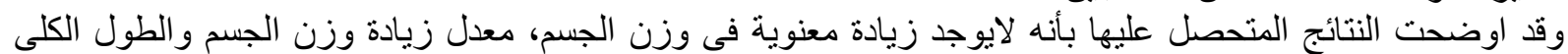

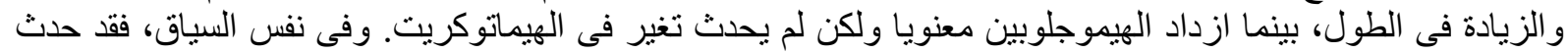

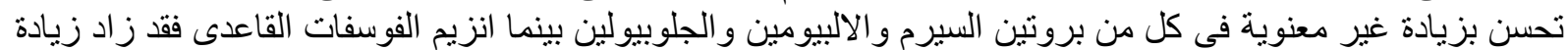

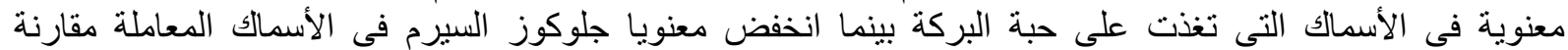

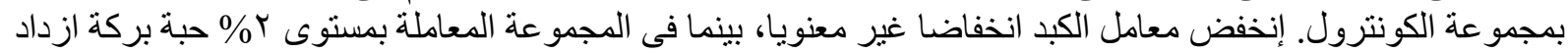

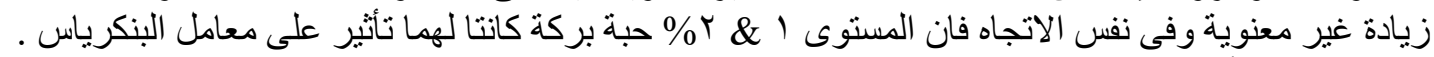

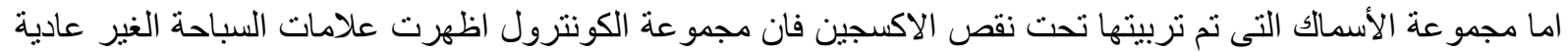

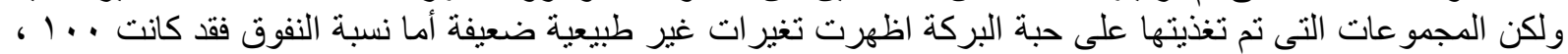

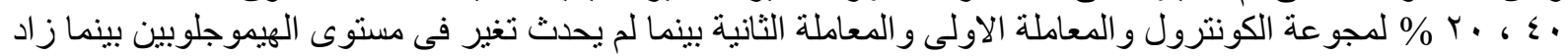

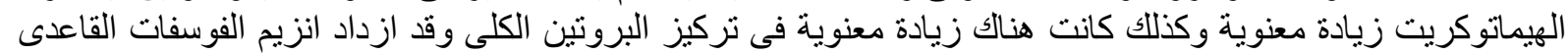

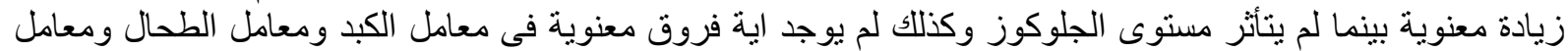

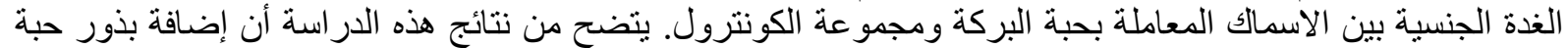

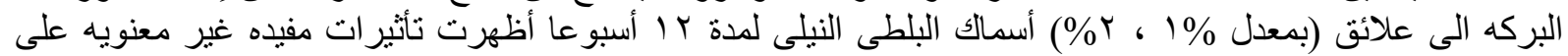

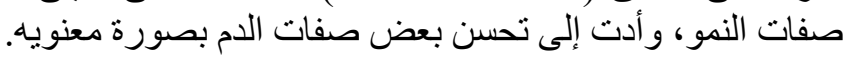

